\title{
Investigation of linearity, detection limit (LD) and quantitation limit(LQ) of active substance from pharmaceutical tablets
}

\author{
AFRODITA DOINA MARCULESCU ${ }^{1}$,CRISTIAN-CATALIN GAVAT ${ }^{2 *}$, AUREL NECHITA ${ }^{3 *}$, GABI TOPOR ${ }^{3}$, \\ LEONARD VASILE VASILESCU ${ }^{1}$, MIHAELA DEBITA ${ }^{3}$, ELENA ROXANA AXENTE ${ }^{3}$, LUCIA CARMEN TRINCA ${ }^{4}$, LUCRETIA ANGHEL ${ }^{3}$ \\ ${ }^{1}$ Grigore T. Popa University of Medicine and Pharmacy, Faculty of General Medicine, Department of Biochemistry, \\ 16 Universitatii Str., 700115, lasi, Romania. \\ ${ }^{2}$ Grigore T. Popa University of Medicine and Pharmacy, Faculty of Medical Bioengineering, Department of Biomedical Sciences, \\ 16 Universitatii Str., 700115, lasi, Romania \\ ${ }^{3}$ Dunarea de J os University of Galati, Medicine and Pharmacy Faculty, Department of Dentistry, 47 Domneasca Str., 800008, Galati, \\ Romania \\ ${ }^{4}$ Ion Ionescu de la Brad University of Agricultural Sciences and Veterinary Medicine of lasi, 3 M. Sadoveanu Alley, 700490, Iasi, \\ Romania
}

\begin{abstract}
The aim of this research was to exactly quantify pure sodium metamizole from tablets, using a spectrophotometric analysis in Visible range. The method applied has been subjected to a validation protocal which consisted in analyzing the following parameters: linearity of the method, detection limit (LD) , quantitation limit (LQ).

Following actual dosing, pure sodium metamizole amount in tablet of pharmaceutical was found to be $477.477 \mathrm{mg}$ assigned to a percentage content of $95.495 \%$, very close to official declared amount (500 $\mathrm{mg}$ ), with an maximum average percentage deviation of only $4.505 \%$ from the official declared active substance content. This value was situated below the maximum admissible percentage deviation from stated active substance content $( \pm 5 \%)$, established by Romanian Pharmacopoeia, $X$-th Edition rules.
\end{abstract}

Keywords: sodium metamizole, detection limit, quantitation limit

Metamizole (dipyrone, as sodium salt) is a popular analgesic medicine, non-opioid drug, commonly used in human and veterinary medicine similar to other natural or synthetic active principles such as black pepper, lavender, pepper, curcumin ibuprofen [1-6]. In some cases, this agent is still incorrectly classified as a non-steroidal antiinflammatory drug (NSAID). Apart from its strong analgesic effect, the medication is an moderate antipyretic and significant spasmolytic agent [7-12]

The spasmolytic effect of metamizole is a result of mechanism associated with a powerfull inhibition of intracellular calcium $\left(\mathrm{Ca}^{2+}\right)$ release, as a result of the reduced inositol phosphate synthesis. Metamizole is predominantly applied in the therapy of pain of different etiology, of spastic conditions, especially affecting the digestive tract[13], and of fever refractory to other treatments. It is especially indicated as an strong, effective analgesic in all types of moderate and intense pain (neuralgia, arthralgia, myalgia, headache, dysmenorrhoea), including postoperative pain, renal and biliary colic, dental pain[14-17]

\section{Experimental part}

Method and procedures

Algocalmin(sodium metamizole) was oxidized by 5.0 $\%$ ammonium orthomolybdate $\left(\mathrm{NH}_{4}\right)_{2} \mathrm{MoO}_{4}$ aqueous solution in a strongly acidic medium $\left(\mathrm{H}_{\mathrm{SO}}, 40 \%\right)$, to form a bluish-colored green compound that showed a maximum absorbtion to $\lambda=690 \mathrm{~nm}$ (fig 1 ).

Visible absorption spectra of green-bluish compound synthetized. Evaluation of maximum absorption wavelength, specific absorptivity and molar absorption coefficient

Sample synthesis from Algocalmin $®$ Zentiva tablets

One Algocalmin tabletwas weighted to find the average mass of pharmaceutical product It was found that mean mass value was $m_{c}=0.5333 \mathrm{~g}$. The official declared content by pharmaceutical company of pure sodium metamizole in tablet was $500 \mathrm{mg}$. Then, 3 tablets were finely crushed and $\mathrm{a}=0.1102 \mathrm{~g}$ of Algocalmin obtained powder were quantitatively brought with a little volume of absolute methanol ( $8 \mathrm{~mL}$ ) into a $\mathrm{V}_{1}=100 \mathrm{~mL}$ volumetric flask. The content was mixed until complete dissolution of sodium metamizole and filled up to the mark with distilled water.<smiles>Cc1c(N(C)CS(=O)(=O)O[Na])c(=O)n(-c2ccccc2)n1C</smiles>

Sodium Metamizole

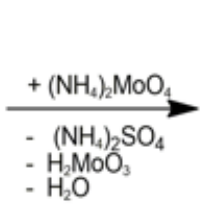<smiles>Cc1c(N(C)C=O)c(=O)n(-c2ccccc2)n1C</smiles>

green-bluish chromogen
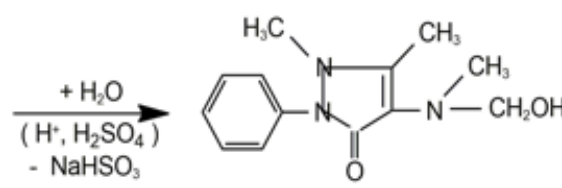

Fig. 1 Chemical reactions of Sodium Metamizole assigned of green-bluish chromogen synthesis

*email: ccgavat70@yahoo.com'Phone: 0743-782544, nechitaaurel@yahoo.com 
From the obtained sample solution, $v_{1}=0.4 \mathrm{~mL}$ were measured and quantitatively brought to $10 \mathrm{~mL}$ graduated glass tube. Then, $1.5 \mathrm{~mL}$ of ammonium orthomolybdate $\left(\mathrm{NH}_{4}\right)_{2} \mathrm{MoO}_{4}, 5.0 \%$ and $0.5 \mathrm{~mL} \mathrm{H}_{2} \mathrm{SO}_{4}, 40 \%$ were added. (table 3). Sample solution was stirred well, stored in a dark place for 30 minutes and filled up to volume $V_{p}=10 \mathrm{~mL}$ with distilled water.

Five measurements have been made and sample mean absorbance Ap, was calculated. (T. 3).

\section{Calculation method}

Calculation of pure sodium metamizole amount in pharmaceutical tablet

The average measured mass of one tablet of pharmaceutical product was $m_{c}=0.5333 \mathrm{~g}(533,3 \mathrm{mg})$. According to manufacturing company, a pharmaceutical tablet of Algocalmin ${ }^{\circledast}$ contained $500 \mathrm{mg}$ of pure sodium metamizole. The amount of pure sodium metamizole existing in final volume of sample solution $\left(V_{p}\right)$ was determined as follows: $X=C_{s}(\mu g / m L) \cdot V_{p}(2)$, whereas $V_{p}=10 \mathrm{~mL}$ has represented sample solution final volume contained in graduated glass tube.

The quantity of pure sodium metamizole from $V_{1}=100$ $\mathrm{mL}$ (volumetric flask) was calculated: $X_{1}=\left(V_{1}{ }^{1} \cdot X\right) / V_{1}$ (3), $v_{1}=0.4 \mathrm{~mL}$ was sample solution volume measured from volumetric flask and quantitatively brought to $V_{p}=$ $10 \mathrm{~mL}$ graduated test tube.

The amount of pure sodium metamizole in tablet of Algocalmin ${ }^{\circledR}$ was investigated as follows: $Y=\left(m_{c} . X_{1}\right) /$ a (4), whereas $a=0.1102 \mathrm{~g}$ fine powder sample of Algocalmin ${ }^{\circledR}$. prepared from pharmaceutical tablets.Y has represented the amount of pure sodium metamizole in tablet sample, expressed as $\mu$ g pure sodium metamizole / tablet, then by transforming into $\mathrm{mg}$ pure sodium metamizole / tablet of Algocalmin ${ }^{\circledR}$ [18-25]

\section{Table 1}

MAXIMUM PERCENTAGE DEVIATIONS FTOM THE STATED CONTENT OF ACTIVE SUBSTANCE IN PHARMACEUTICALS

\begin{tabular}{|c|c|}
\hline Declared content of active substance & $\begin{array}{c}\text { Maximum accepted } \\
\text { percentage deviations }\end{array}$ \\
\hline up to $10 \mathrm{mg}$ & $\pm 10 \%$ \\
\hline $10 \mathrm{mg}$ and up to $100 \mathrm{mg}$ & $\pm 7,5 \%$ \\
\hline $100 \mathrm{mg}$ and over $100 \mathrm{mg}$ & $\pm 5 \%$ \\
\hline
\end{tabular}

Percentage content of pure sodium metamizole in commercial tablet (Z\%):if it was known that one tablet of Algocalmin ${ }^{\circledR}$ had $500 \mathrm{mg}$ of pure sodium metamizole:

$Z=\left(100 . Y_{1}\right) / 500(\%)$, so $Z=Y_{1} / 5(\%)(5), Y_{1}$ has been expressed in $\mathrm{mg}$.
Linearity of the method. Regression line parameters. The linearity of analysis process consisted of the ability to lead to results directly proportional to the concentration of an analyte in a given sample, within a given range (1-40 $\mathrm{\mu g} /$ $\mathrm{mL}$ ), Practically, the intensity of analytical signal (measured absorbance) has varied in directly proportion to the concentration, for a given area. Correlation coefficienthad to be $R>0.999$ and linear regression coefficient $R^{2} e^{T M}$ $0.999[10,11]$. The statistic parameters of method linearity were then determined, using Microsoft Office Excel 2016 software and described in table 4.

Detection limit (LD) was the smallest amount of analyte that could be detected in a sample compared to a blank, under established experimental conditions. It was expressed in the same units as concentration of the analyte (ig/mL) and was evaluated using formula: $L D=3$. SE/ slope (6). SE has represented standard error of the regression line [18-26]

Quantitation limit (LQ) was given by the lowest analyte concentration in a sample, which could be quantified (determined) with acceptable precision and accuracy under the same experimental conditions. Its value was expressed in the same units as analyte concentration (ig/ $\mathrm{mL}$ ) and was calculated as follows: $L Q=10$. SE / slope (7) [18-27].

\section{Results and discussions}

Visible absorption spectra of green-bluish compound. Maximum absorption wavelength, specific absorptivity and molar absorption coefficient investigation

Absorption spectra of green-bluish chromogen was plotted for $7 \mu \mathrm{g} / \mathrm{mL}$ solution (fig. 2 ) and maximum absorption wavelength was determined to $\lambda=690 \mathrm{~nm}$. Mean measured absorbance value to this wavelength was $\mathrm{A}=0.1653$. Concentration of $7 \mu \mathrm{g} / \mathrm{mL}$ was transformed as follows: $7 \mu \mathrm{g} / \mathrm{mL}=0.0007 \mathrm{~g} / 100 \mathrm{~mL}$ and was assigned to a $2.853 .10^{-5}$ mole/L concentration, with the respect of calculated molecular weight corresponded to green-bluish chromogen, which was $\mathrm{M}=245.338 \mathrm{~g} / \mathrm{mole}$ (fig.3).

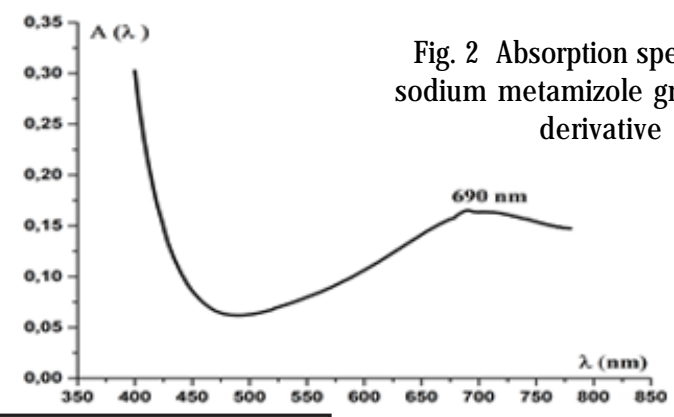

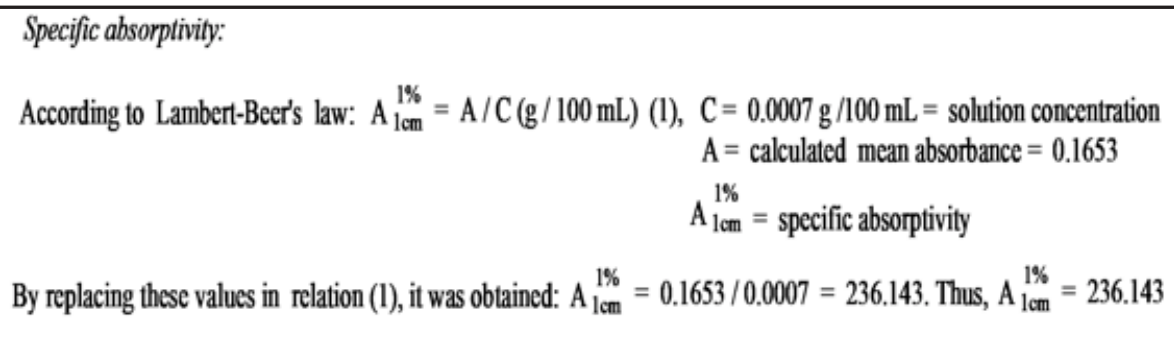

Molar absorption coefficient: Similarly, $\mathrm{E}_{\text {molar }}=\mathrm{A} / \mathrm{C}$ (mole $\left./ \mathrm{L}\right)(2), \mathrm{C}=2.853 .10^{-5}$ mole $/ \mathrm{L}=$ solution concentration

$$
\mathrm{M}_{\text {gren-bluish compund }}=245.338 \mathrm{~g} / \mathrm{mole}
$$

$\mathrm{A}=$ calculated mean absorbance $=0.1653$

$\mathrm{E}_{\text {molar }}=$ molar absorption coefficient
Fig. 3 Specific absorptivity and molar absorption coefficient calculation

By replacing these values in relation (2), it was obtained: $\mathrm{E}_{\text {molar }}=0.1653 .10^{5} / 2.853=5793.901$. Thus, $\mathrm{E}_{\text {molar }}=5793.901$ 
Table 2

MEASURED ABSORBANCES OF SODIUM METAMIZOLE STANDARD SOLUTUONS

\begin{tabular}{|c|c|c|c|c|c|}
\hline No. det & $\begin{array}{c}\text { mL sodium metamizole } 100 \\
\mu \mathrm{g} / \mathrm{mL} \text { (standard) }\end{array}$ & $\mathrm{mL}\left(\mathrm{NH}_{4}\right)_{2} \mathrm{MoO}_{4} 5 \%$ & $\begin{array}{c}\mathrm{mL} \mathrm{H}_{2} \mathrm{SO}_{4}, \\
40 \%\end{array}$ & $\mathrm{C}(\mu \mathrm{g} / \mathrm{mL})$ & $\mathrm{A}(\delta)$ \\
\hline 1. & 0.1 & 1.5 & 0.5 & 1.0 & 0.0130 \\
\hline 2. & 0.2 & 1.5 & 0.5 & 2.0 & 0.0432 \\
\hline 3. & 0.3 & 1.5 & 0.5 & 3.0 & 0.0708 \\
\hline 4. & 0.4 & 1.5 & 0.5 & 4,0 & 0,0920 \\
\hline 5. & 0.5 & 1.5 & 0.5 & 5.0 & 0.1180 \\
\hline 6. & 1.0 & 1.5 & 0.5 & 10.0 & 0.2360 \\
\hline 7. & 1.5 & 1.5 & 0.5 & 15.0 & 0.3440 \\
\hline 8. & 2.0 & 1.5 & 0.5 & 20.0 & 0.4620 \\
\hline 9. & 2.5 & 1,5 & 0.5 & 25.0 & 0.5800 \\
\hline 10. & 3.0 & 1.5 & 0.5 & 30.0 & 0.7080 \\
\hline 11. & 3.5 & 1.5 & 0.5 & 35.0 & 0.8120 \\
\hline 12. & 4.0 & 1.5 & 0.5 & 40.0 & 0.9350 \\
\hline
\end{tabular}

Table 3

SAMPLE CONCENTRATION AND SODIUM METAMIZOLE PURE AMOUNTS DETERMINED IN TABLET

\begin{tabular}{|c|c|c|c|c|}
\hline $\begin{array}{c}\text { Algocalmin } \\
\text { sample }\end{array}$ & As & $\mathrm{Cs}_{\mathrm{S}}(\mu \mathrm{g} / \mathrm{mL})$ & $\begin{array}{c}\mu \mathrm{g} \text { sodium metamizole } \\
\text { /tablet }\end{array}$ & $\begin{array}{c}\text { mg sodium metamizole } \\
\text { tablet }\end{array}$ \\
\cline { 2 - 5 } & 0.9204 & 39.466 & 477477.717 & $\mathbf{4 7 7 . 4 7 7}$ \\
\hline
\end{tabular}

Linearity of the method -regression line drawing and characteristics

Determined absorbances values of standard solutions measured to $\lambda=690 \mathrm{~nm}$, were listed in table 2 .

Investigation of sodium metamizole concentration $(\mu \mathrm{g} /$ $\mathrm{mL}$ ) in Algocalmin ${ }^{\circledR}$ sample solution

Mean absorbance of Algocalmin ${ }^{\circledR}$ sample containing sodium metamizole as active substance, sodium metamizole concentration which was expressed in $\mu \mathrm{g} /$ $\mathrm{mL}$, as well as the amount of pure sodium metamizole calculated in tablet of pharmaceutical product, were shown in table 3.

From relation (1): $C_{s}=\left(A_{s}+0.0031\right) / 0.0234(\mu \mathrm{g} / \mathrm{mL})$ $=(0.9204+0.0031) / 0.0234$, so $C_{\mathrm{s}}=39.466 \mu \mathrm{g} / \mathrm{mL}$ has represented sample concentration of pure sodium metamizole.

Calculation of pure sodium metamizole amount on pharmaceutical tablet Algocalmin ${ }^{\circledR}$

Pure sodium metamizole amount existing in final volume of sample solution $\left(\mathrm{V}_{\mathrm{p}}=10 \mathrm{~mL}\right)$ according to equation (2), was: $X=39.466 \cdot 10=394,66 \mu \mathrm{g}$.

Sodium metamizole quantity from $\mathrm{V}_{1}=100 \mathrm{~mL}$ (volumetric flask) was calculated, as follows: $X_{1}=(100$. 394.66) $/ 0.4$, according to relation (3). So, $X_{1}=98665 \mu \mathrm{g}$.

The amount of pure sodium metamizole in tablet of pharmaceutical product $: Y=(0.5333 .98665) / 0.1102=$ $477477.717 \mu \mathrm{g}$ sodium metamizole. Thus, $\mathrm{Y}_{1}=477,477$ mg pure sodium metamizole / tablet of pharmaceutical Algocalmin $\circledR_{\text {. }}$

Percentage content of pure sodium metamizole in commercial tablet ( $Z \%)$ : it is known that one tablet of Algocalmin ${ }^{\circledR}$ had a content of $500 \mathrm{mg}$ pure sodium metamizole, so $Z=477,477 / 5=95.495 \%$ revealed by equation (5). Thus, $Z=95.495 \%$ has expressed sodium metamizole percentage contents in tablet.

Calculated pure sodium metamizole value has represented $95.495 \%$ from the officially declared value (500 $\mathrm{mg}$ ) by the pharmaceutical company and it had an average maximum percentage deviation of only $4.505 \%$ from the official pure declared active substance content.
Regression statistic parameters evaluation

Statistic parameters of method linearity which have been determined in MicrosoftExcel 2016, were presented in table 4.

Table 4

STATISTIC VALUES OF LINEAR REGRESSION PARAMETERS

\begin{tabular}{|l|l|}
\hline \multicolumn{2}{|l|}{ Regression Statistics } \\
\hline Multiple R (Correlation coefficient) & 0.999898 \\
\hline R Square R'(Linear regression coefficient) & 0.999795 \\
\hline Adjusted R Square R ${ }^{2}$ & 0.999775 \\
\hline Standard Error (SE) & 0.004882 \\
\hline Observations & 12 \\
\hline
\end{tabular}

Ecuation of the regression line was: $y=0.0234 . x$ 0.0031 , or $A_{s}(\lambda)=0.0234 . C_{s}(\mu \mathrm{g} / \mathrm{mL})-0.0031$. The intercept was (-) 0.0031 and slope : 0.0234. Linear regression coefficient was $R^{2} \geq 0.999$ and correlation coefficient $R>0,999$ were above minimum admisible value (table 3) and were situated within the normal range of values, which demonstrated the linear variation of measured standard solutions absorbances coresponding to their concentrations. Standard error of the regression line (SE) was SE $=0.004882$ (table 3) had a coresponding, highly low value.

Detection limit (LD) and quantitation limit (LQ); Detection limit was, $L D=3.0 .004882 / 0.0234$, thus LD $=0.626 \mu \mathrm{g} / \mathrm{mL}$. according to relation (6) and Quantitation limit was assigned with $L Q=10.0 .004882 / 0.0234$, so $\mathrm{LQ}=2.086 \mu \mathrm{g} / \mathrm{mL}$, from equation (7).

\section{Conclusions}

The method used for Visible spectrophotometric analysis of sodium metamizole in tablets marketed under the name Algocalmin Zentiva ${ }^{\circledR}$, was linear in standard concentrations range $1 \mathrm{Eg} / \mathrm{mL}-40 \mathrm{Eg} / \mathrm{mL}$; the linear regression coefficient was $R^{2}=0.999795, R^{2} \geq 0.999$ and corelation coefficient $R$ $=0.999898, R>0.999$. Standard error of the regression line $\mathrm{SE}=0.004882$, detection limit $\mathrm{LD}=0.626 \mathrm{Eg} / \mathrm{mL}$ and quantitation limit $\mathrm{LQ}=2.086 \mathrm{Eg} / \mathrm{mL}$ were located within the normal range of values. 
Visible spectrophotometric (VIS) method used for quantitative analysis of sodium metamizole in tablets has been successfully validated through the complete scrolling of studied stages and could be applied in practice to active substance dosing from different samples.

New methods for detecting the active principles in the various of pharmaceutical forms with spectacular results are Ordered mesoporous carbon based sensor for Sensitive detection or Electrochemical determination [28-29].

Acknowledgments. This study is simply a scientific research paper that does not aim to confirm or deny the official results of pharmaceutical manufacturing company, nor to cause any image damage.

\section{References}

1.DUMITRIU BUZIA, O, MARDARE, N, FLOREA, A, DIACONU, C, DINICA, R.M.,TATU, A.L..Formulation and preparation of pharmaceuticals with anti-rheumatic effect using the active principles of capsicum annuum and piper nigrum, Rev.Chim. (Bucharest), 69, no.10, 2018, p. 2854 2.NICULET, E., NECULIA, G.V.,TATU, A.L., DUMITRIU BUZIA, 0. Curcumin- Extraction, Physical and Chemical Analysis, Formulas and Control. Basic Methods for Further Research, Mat. Plast., 55, no. 4, 2018

3.MIHAILA, B., DINICÃ, R/M., TATU, AL, DUMITRIU BUZIA,O, New insights in vitiligo treatments using bioactive compounds from Piper nigrum. Exp Ther Med.2018. doi.org/10.3892/etm.2018.6977

4.ROBU S., CHESARU B.I, DIACONU C., DUMITRIU BUZIA.O., TUTUNARU D, STANESCU U, LISA E.L.,Lavandula hybrida: microscopic characterization and the evaluation of the essential oil Farmacia, 2016, vol. 64, 6.914-917

5.IRINA MIRELA APETREI, ADRIANA AURORA BEJINARU, MONICA BOEV, CONSTANTIN APETREI, OLIMPIA DUMITRIU BUZIA, Determination of ibuprofen based on screen-printed electrodes modified with carbon nanofibers, Revista Farmacia, 2017, vol. 65, 5,790-795

6.DUMITRIU BUZIA.,O, FASIE, V., MARDARE, N., DIACONU, C., GURAU, G.,TATU, AL., Formulation,Preparation, Physico-chimical Analysis, Microbiological Peculiarities and Therapeutic Challenges of Extractive Solution of Kombucha, Rev. Chim. (Bucharest), 69, no. 3, 2018, p. 720 7.*** Farmacopeea Romana, 10, Edit. Medicala, Bucuresti, 1993, p. 977-1293.

8.ADRIANA, N., DELIA, MIRELA, T., LUCIAN, C., CARMEN, ELENA, M., (F.), DANA, MARIA, C., SIMONA, B., CIPRIAN, I., Rev. Chim. (Bucharest), 69, no. 2, 2018, p. 297-299.

9. ANNA, J., TOMASZ, M., JERZY, JAN, J., Polish J ournal of Veterinary Sciences, 17, nr. 1, 2014, p 207-214.

10.LOGHIN, I., EARAR, K., NECHITA, A., SANDU, I.G., DOROBAT, C., MATEI, M.N. Rev. Chim. (Bucharest), 66, no.3, 2015, p. 387-389.

11.BEJ AN, C., MATEI, M.N., DOROBAT, C., JUGANARIU, G., DOROBAT, G., CONSTANTINESCU, S., NECHITA, A., EARAR, K., Rev. Chim. (Bucharest), 66, no.2, 2015, p. 282-284.
12.ARBUNE, M., FOTEA, S., NECHITA, A., STEFANESCU, V. JOURNAL OF CRITICAL CARE MEDICINE, 4, no. 3, 2018, p. 96-100

13.DRAGANESCU M,BAROIU N, BAROIU L,DIACONU C,DUMITRIU BUZIA.O.,Efficeint administration of human albumin in clostridium Difficile infection, Rev. Chim.(Bucharest),68, no. 3 ,2017, p. 602-604 14.KAPIL KALRA, (2011). Method Development and Validation of Analytical Procedures, Quality Control of Herbal Medicines and Related Areas, Prof. Yukihiro Shoyama (Ed.)

15.KARAM, MOHAMAD, A., ALI, M., MOSTAFA, I., MUSTAFA, B., Indo American J ournal of Pharmaceutical Research, 7, nr. 4, 2017, p. 81798184.

16. LAXMI, B., JAY, KUMAR, C., PRABHAT, P., J ournal of Drug Delivery \& Therapeutics; 3, nr. 6, 2013, p., 87-90.

17.MONA B., SUBRAHMANYAM, E.,V.,S., SHABARAYA, A.,R., International Journal of Pharma Sciences and Research (IJPSR), 6, nr.2, 2015, p. 411-413. .

18. MUBEEN, G., VINEETA, P., SOMASHEKAR, P., L., KADRI, U., International J ournal of Chem Tech Research, 1, nr.2, 2009, p. 318321.

19.MUNIOZ, J, NAVARO, C., NORIEGA, V., PINARDI, G., SIERALTA, F., PRIETO, J.,C., MIRANDA, H.,F., Inflammopharmacology, 18, nr.2, 2010, p 65-71.

20.PRADEEP, S., VIKASH, KUMAR, C., PRAVEEN, KUMAR, V., AMIT, KUMAR, S., VIJ AY, KUMAR, Y., International J ournal of Research and Development in Pharmacy and Life Sciences, 4, nr.1, 2015, p. 13751378.

21.BURKHARD, H., OLGA, C., JOURI, B., BERTOLD, R., OLIVER, Z., MARTIN, F. ,F., KAY, B., FASEB J ournal, 21, nr. 10, 2007, p 2343-2351. 22.PIERRE, S.,C., SCHMIDT, R., BRENNEIS, C., MICHAELIS, M., GEISSLINGER, G, SCHOLICH, K., British Journal of Pharmacology, 151, 2007, p 494-503.

23.STEPHAN, S., ANDREAS, M., Best Practice \& Research Clinical Anaesthesiology, 21, nr. 1, 2007, p 15-30

24.DORNEANU, V., STAN, M., Metode Chimice si Instrumentale de Analiza, Edit. Universitatii de Medicina si Farmacie Gr.T.Popa, Iasi, 2007, p. 236-332.

25.DORNEANU, V., STAN, M., MUSTEATA, M., F., Chimie Analitica, Edit. U.M.F. Gr.T. Popa, lasi, 2003, p. 164-500

26.COBZEANU, BM., IRIMICIUC, S., VAIDEANU, D., GRIGOROVICI, A., POPA, O., Mat. Plast., 54, no.3, 2017, p.531-534

27.GRIGOROVICI, A., CHERCIU, MS., POPESCU, CM., APOSTOL, DGC., PREDA, C., CALIN, A., AELENEI, P., FARMACIA, 65, no.1, 2017, p.29-39 28.IRINA MIRELA APETREI, ADRIANA AURORA BEJINARU, MONICA BOEV, CONSTANTIN APETREI, OLIMPIA DUMITRIU BUZIA, Determination of ibuprofen based on screen-printed electrodes modified with carbon nanofibers, Revista Farmacia, 2017, vol. 65, 5,790-795

29.IRINA MIRELA APETREI, CONSTANTIN APETREI, OLIMPIA DUMITRIU BUZIA Ordered mesoporous carbon based sensor for Sensitive detection of vitamin b6 in pharmaceuticals,Farmacia, 2016, Vol. 64, 4 Pages: 790-795, pag.544-548 http://www.revistafarmacia.ro/Factor de impact 1.507

$\overline{\text { Manuscript received:14.07.2018 }}$ 